\title{
A NOVEL METHOD BASED ON BISECTION SEARCH ALGORITHM FOR EXTRACTING THE REFERENCE PARAMETERS OF PV MODULES
}

\author{
Ceyhun KAPUCU*, Department of Informatics, Muğla Sitki Kocman University, Mugla, Turkey, ckapucu@gmail.com \\ (iD https://orcid.org/0000-0003-0563-235X) \\ Mete ÇUBUKÇU, Solar Energy Institute, Ege University, Izmir, Turkey, metecubukcu04@gmail.com \\ (iD) https://orcid.org/0000-0001-5060-4302)
}

Received: 06.08.202019, Accepted: 10.10 .2019

Research Article

*Corresponding author

DOI: $10.22531 /$ muglajsci.602222

\begin{abstract}
Manufacturers generally share datasheet values of photovoltaic (PV) modules at only standard test conditions (STC). These conditions enable PV modules to generate high power but are rarely encountered in the real environment. Therefore, accurate modeling of PV modules is very important in terms of estimating the energy that can be obtained under all operating conditions. Many studies have been conducted in this field in the literature. In this study, a new method is proposed for the implementation of the commonly used five-parameter model. This new method uses a bisection search algorithm for calculating the value of the series resistance, which is one of the five parameters, and thus extracting the other parameters. The datasheet values provided by the manufacturers are sufficient for obtaining the series resistance and therefore other parameters. The accuracy of the method was first tested by comparing the datasheet values of the three different PV modules with the outputs of the proposed method. Finally, the simulation accuracy of the proposed method for different operating conditions was tested by comparing the real measurement data collected by the National Renewable Energy Laboratory (NREL) with the outputs of the method under the same operating conditions. The results show that the proposed method demonstrates good agreement with both datasheet values and real measurement data. The method offers a good balance of simplicity-accuracy.
\end{abstract}

Keywords: Photovoltaic modelling, Bisection search algorithm, Five-parameter model

\section{FOTOVOLTAİK MODÜLLERİN REFERANS PARAMETRELERINIIN ÇIKARILMASI IÇİN İKIYE AYIRMALI ARAMA ALGORITMASI TEMELLİ YENİ BİR YÖNTEM}

\section{Özet}

Üreticiler genellikle fotovoltaik (PV) modüllerin standart test koşullarındaki veri sayfası değerlerini paylaşmaktadırlar. Bu koşullar PV modüllerinin yüksek güç üretmesini sağlar, ancak gerçek ortamda nadiren karşılaşılır. Bu nedenle, PV modüllerin doğru modellenmesi, her türlü çalışma koşulunda elde edilebilecek enerjinin tahmin edilebilmesi açısından oldukça önemlidir. Literatürde bu alanda pek çok çalışma yapılmıştır. Bu çalışmada, yaygın kullanılan beş-parametreli modelin uygulanmasında yeni bir yöntem önerilmektedir. Bu yeni yöntem, beş parametreden biri olan seri direncin değerini hesaplamak ve böylelikle diğer parametrelerin çıkarılması için ikiye ayırmalı bir arama algoritması kullanmaktadır. Seri direncin ve dolayısıyla diğer parametrelerin elde edilmesinde üreticilerin sunduğu veri sayfası değerleri yeterli olmaktadır. Yöntemin doğruluğu, ilk olarak, üç farklı PV modülün veri sayfası değerleri ile önerilen yöntemin çıktılarının karşılaştırılmasıyla test edilmiştir. Son olarak, önerilen yönteminin farklı çalışma şartları için simülasyon doğruluğu ise Ulusal Yenilenebilir Enerji Laboratuvarı (NREL) tarafından toplanan gerçek ölçüm verilerinin, yöntemin aynı çalışma şartlarındaki çıktılarıyla karşılaştırılmasıyla test edilmiştir. Sonuçlar, önerilen yöntemin hem veri sayfası değerleri hem de gerçek ölçüm verileri ile iyi bir uyum sağladığını göstermektedir. Yöntem iyi bir basitlik-doğruluk dengesi sunmaktadır. Anahtar Kelimeler: Fotovoltaik modelleme, İkiye ayırmalı arama algoritması, Beş parametreli model

Cite

Kapucu, C., Çubukçu, M. (2019). "A novel method based on bisection search algorithm for extracting the reference parameters of PV modules", Mugla Journal of Science and Technology, 5(2), 81-90.

\section{Introduction}

The rising research and development studies in the domain of photovoltaic (PV) systems have made the PV systems a well-known alternative energy resource. PV systems convert incident solar irradiation directly to electrical energy [1]. The simplest component of a PV system is the PV cell. The cells may be connected electrically to form modules or arrays. Developing new and more efficient cells with the help of evolving technology allows reducing costs of manufacture. The output character of a PV module is highly nonlinear and 
depends on irradiation level and module temperature. In order to design an efficient PV system, it is important to predict PV device behavior accurately at all operating conditions. The most common technique to simulate the characteristic of PV devices is to use an equivalent circuit model [2]-[9].

The main challenge when using methods based on equivalent circuit models is how to extract the parameters that ensure accuracy in various operating conditions. In the literature, different parameter extraction methods using equivalent circuits like the fiveparameter model have been presented [3], [4], [13]-[15], [5]-[12]. The most practical approach is using datasheet values provided by the manufacturers [16].

The proposed method in Reference [10] uses only datasheet values with several implicit equations to solve. The method requires prior calculation of the five parameters at reference conditions. The results are used to calculate the parameters and thus the power output at any operating conditions.

The method proposed in Reference [4] uses the manufacturer's datasheet values to extract the five parameters and it has one implicit equation to handle. The method iteratively adjusts the parameters, until the model's maximum power $\left(P_{m}\right)$ matches the $P_{m}$ in the manufacturer's datasheet. Although it is widely used due to high accuracy, calculating the whole curve in each iteration step dramatically slows the extraction process.

Methods proposed in References [2], [5], [17] required the measurement of the I-V curve slope at open-circuit and short-circuit points. Generally, the manufacturer's datasheet does not include these slope data. These slope data can be obtained from the graphical representation of the I-V curve. Even if the curve is given, it is sometimes a generic curve given by the manufacturer for more than one types of PV modules [13]. Also due to its always being approximate, a graphical estimation cannot avoid producing measurement errors that can affect the results [18].

While in References [2], [4], [5], [9], [10], an iterative algorithm was used, Reference [17] did not require any iteration. According to [16], iterative methods were generally used to solve series and parallel resistance. Some of these methods require initial estimations of various parameters. For example, an initial guess for diode ideality factor in Reference [4], series resistance in Reference [2], diode ideality factor and the series resistance in Reference [5], light-generated and reverse saturation currents, the series and parallel resistances in Reference [10] were required before parameter extraction. The method proposed in [9] used iteration for searching the exact series and parallel resistance pair that guarantees that the voltage-derivative of the power equals zero at the maximum power point (MPP). In addition, they suggested an equation to calculate the possible maximum value of series resistance. Although it avoids solving implicit equations, the linear approximation for searching series and parallel resistance causes slow convergence problem.

A literature review and comparison through parameter extraction methods can be found in References [16], [18], [19]. While References [16] and [19] have proposed a systematical review of important works based on singlediode and two-diode equivalent circuit for PV modeling and parameter extraction of PV devices, in [18], five different PV modeling and parameter extraction methods have been compared including References [2], [4], [5], [10], [17].

In this paper, an effective improvement for the method described in [9] is presented to get better accuracy with lower computational time and iteration steps. In the proposed method, a new search algorithm is used to make iteration converge quickly.

The rest of this paper is sorted out as follows. In section 2 , the proposed method is depicted. In section 3 , the validity of the model is tested by its application to various PV modules and comparison with real outdoor data. Finally, the obtained conclusions are outlined in section 4.

\section{Materials and Methods}

Equivalent circuit representation of the single-diode model is shown in Figure 1. This model consists of a voltage-dependent current source, a series resistor, a p$\mathrm{n}$ junction diode in parallel with a shunt resistor. The I-V characteristic of this model at a fixed cell temperature and solar irradiation is defined by the following wellknown implicit equation [1]-[7], [10], [11], [17]:

$$
\begin{gathered}
I=I_{L}-I_{D}-I_{R_{p}} \\
=I_{L}-I_{o}\left[\exp \left(\frac{V+I R_{s}}{V_{t} a}\right)-1\right]-\frac{V+I R_{s}}{R_{p}}
\end{gathered}
$$

where $I_{L}$ is the light-generated current, $I_{D}$ is the Shockley diode equation, $I_{o}$ is the reverse saturation current of the diode, $V_{t}=N_{s} k T / q$ is the thermal voltage of the diode, $a$ is the diode ideality factor, $N_{s}$ is number of the cells in series in a single module, $k$ is the Boltzmann constant $\left(1.3806503 \times 10^{-23} \mathrm{~J} / K\right), T$ is the temperature of the cell $(K), q$ is the electron charge $\left(1.60217646 \times 10^{-19} C\right) . R_{S}$ is the series resistance and $R_{p}$ is the parallel resistance. Five parameter of this equation $\left(I_{L}, I_{o}, a, R_{s}\right.$ and $\left.R_{p}\right)$ must be known to calculate the current and voltage output of the PV device powering the load in an application.

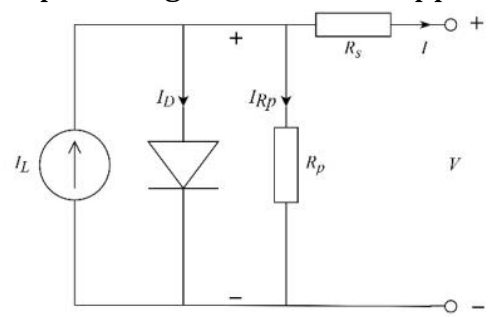

Figure 1. Equivalent circuit representation of the singlediode model.

In general, the manufacturers give datasheet values at specific reference conditions only. These values include 
the short-circuit current $\left(I_{s c n}\right)$, the open-circuit voltage $\left(V_{o c n}\right)$, the voltage $\left(V_{m n}\right)$, the current $\left(I_{m n}\right)$ and the power $\left(P_{m n}\right)$ at the MPP. In some cases, the short-circuit current temperature coefficient $\left(K_{i}\right)$ and the open-circuit voltage temperature coefficient $\left(K_{v}\right)$ are also included in datasheets [16].

At the MPP, the voltage-derivative of the power equals zero [10].

$$
\begin{aligned}
\left.\frac{\mathrm{d} P}{\mathrm{~d} V}\right|_{V=V_{m n}, I=I_{m n}} & =\left.\frac{\mathrm{d}(I V)}{\mathrm{d} V}\right|_{V=V_{m n}, I=I_{m n}} \\
& =I_{m n}+\left.V_{m n} \frac{\mathrm{d} I}{\mathrm{~d} V}\right|_{V=V_{m n}, I=I_{m n}}=0
\end{aligned}
$$

By differentiating current $(I)$ with respect to voltage $(V)$ in Eq. (1) and substituting $I_{m n}$ and $V_{m n}$ into the equation, we have Eq. (3) [10]:

$$
\begin{aligned}
& \left.\frac{\mathrm{d} I}{\mathrm{~d} V}\right|_{V=V_{m n}, I=I_{m n}} \\
& =\frac{\frac{-I_{o n}}{a_{n} V_{t n}} \exp \left(\frac{V_{m n}+I_{m n} R_{s n}}{a_{n} V_{t n}}\right)-\frac{1}{R_{p n}}}{1+\frac{I_{o n} R_{s n}}{a_{n} V_{t n}} \exp \left(\frac{V_{m n}+I_{m n} R_{s n}}{a_{n} V_{t n}}\right)+\frac{R_{s n}}{R_{p n}}}
\end{aligned}
$$

From Eq. (3), we extract Eq. (4).

$$
I_{\text {on }}=\frac{I_{s c n}}{\exp \left(\frac{V_{o c n}}{a_{n} V_{t n}}\right)-1}
$$

where $I_{o n}$ is the diode's reverse saturation current at STC, $a_{n}$ is the diode ideality factor, $V_{t n}=N_{s} k T_{n} / q$ is the thermal voltage of the diode and $T_{n}(298.15 K)$ is the temperature of the cell $(K)$ at STC. The diode ideality factor $a_{n}$ can be chosen as a constant. Varying this constant slightly effects the shape of the $I-V$ curve [4], [20].

Figure 2 shows the typical $I-V$ and $P-V$ curves for a PV module. As shown in the figure at the MPP, the voltagederivative of the power equals zero. As we move from the MPP to the left on that curve, this derivative becomes greater than zero, for the opposite direction, the derivative becomes smaller than zero [9].

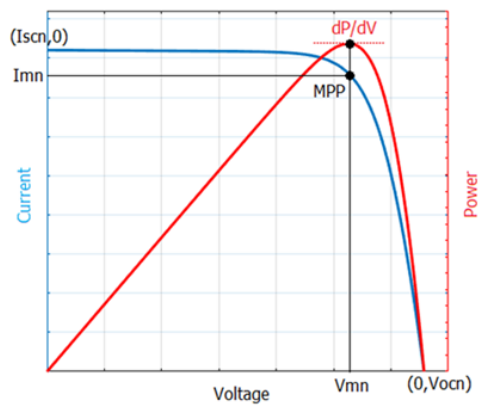

Figure 2. I-V curve and P-V curve for a PV module.

In Eq. (3), $R_{s n}$ and $R_{p n}$ resistance values are unknown. These parameters are calculated using the short-circuit point and the MPP values in Eq. (1) [9].
By substituting short-circuit point values $\left(I=I_{s c n}, V=\right.$ 0 ) into the Eq. (1), we have Eq. (5):

$$
I_{s c n}=I_{L n}-I_{o n}\left[\exp \left(\frac{I_{s c n} R_{s n}}{V_{t n} a_{n}}\right)-1\right]-\frac{I_{s c n} R_{s n}}{R_{p n}}
$$

where $I_{L n}$ is the light-generated current at STC. In this equation, since $I_{o n}$ is very close to zero, the second part of the right side of Eq. (5) can be disregarded [21].

$$
I_{L n}=I_{s c n} \frac{R_{p n}+R_{s n}}{R_{p n}}
$$

By substituting the MPP values $\left(I=I_{m n}, V=V_{m n}\right)$ into the Eq. (1), we have Eq. (7):

$$
\begin{aligned}
I_{m n}=I_{L n}-I_{o n}[ & \left.\exp \left(\frac{V_{m n}+I_{m n} R_{s n}}{V_{t n} a_{n}}\right)-1\right] \\
& -\frac{V_{m n}+I_{m n} R_{s n}}{R_{p n}}
\end{aligned}
$$

By substituting Eq. (6) into Eq. (7), we extract Eq. (8) to calculate $R_{p n}$ with an explicit function of $R_{s n}$ [21].

$$
R_{p n}=\frac{I_{s c n} R_{s n}-V_{m n}-I_{m n} R_{s n}}{I_{m n}+I_{o n}\left[\exp \left(\frac{V_{m n}+I_{m n} R_{s n}}{V_{t n} a_{n}}\right)-1\right]-I_{s c n}}
$$

In Figure 3 the relation of $R_{s n}$ and $R_{p n}$ based on Eq. (8) is shown. As shown in the figure $R_{p n}$ shows rapid changes when $R_{s n}$ is close to a specific resonance point $R_{s n r}$ [9]. When this resonance point is passed, $R_{p n}$ becomes negative, which is meaningless. Therefore, we can conclude $R_{s n r}$ as the maximum value for $R_{s n}$ at STC [21]. By equating the divisor of the right side of Eq. (8) to zero, we have Eq. (9) for obtaining $R_{\text {snr }}$.

$$
R_{s n r}=\frac{V_{t n} a_{n} \ln \left(\frac{I_{s c n}-I_{m n}}{I_{o n}}+1\right)-V_{m n}}{I_{m n}}
$$

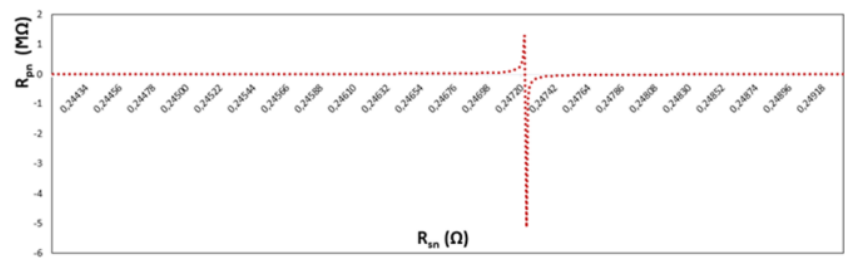

Figure 3. Relation of $R_{s n}$ and $R_{p n}$ based on Eq. (8).

After obtaining $R_{\text {snr }}$ Wang et al. suggested an iterative algorithm to search the exact pair $\left\{R_{s n}, R_{p n}\right\}$ that guarantees that the voltage-derivative of the power equals zero at the MPP. Their search algorithm starts $R_{s n}$ from zero and then increases its value and recalculate $R_{p n}$ and the derivative in every step, until the derivative based on Eq. (2), turns from positive to negative by crossing the point where the derivative equals zero. $R_{s n}$ value at the crossing point can be calculated by the following equation:

$$
R_{s n}=R_{s n 1}+\left(R_{s n 2}-R_{s n 1}\right)\left(\frac{d P / d V_{1}}{d P / d V_{1}-d P / d V_{2}}\right)
$$

where $d P / d V_{1}$ is the calculated derivative for the series resistance value $R_{s n 1}$ and $d P / d V_{2}$ is the calculated derivative for the series resistance value $R_{s n 2}$. 
In this paper, a new searching approach for the appropriate series resistance is suggested. Instead of starting $R_{s n}$ from zero and increasing it step by step linearly, bisection search algorithm is used to search $R_{s n}$. Suggested algorithm considers Eq.(2) as a continuous function in the interval $\left\{0, R_{\text {snr }}\right\}$. The aim of the algorithm is finding the root of the function by halving the interval in every iteration steps until the root is found or the interval is small enough. The flow diagram of the suggested algorithm is shown in Figure 4.

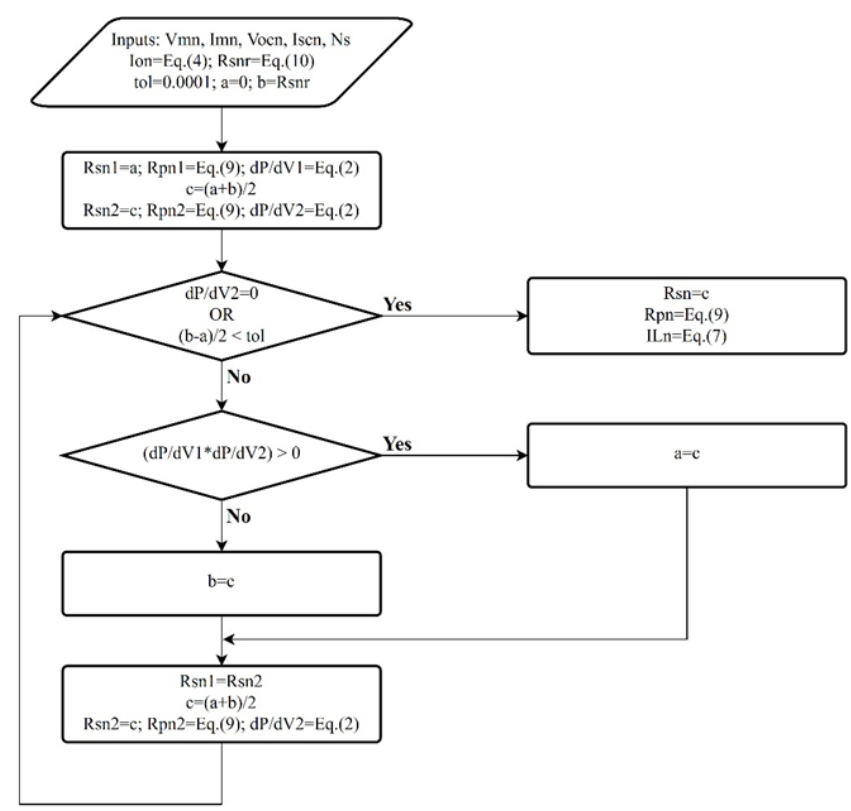

Figure 4. Flow diagram of the suggested algorithm.

As the output character of a PV module is highly nonlinear and depends on irradiation level and module temperature, the extracted parameters at reference conditions should be adjusted for operating conditions with the Eqs. (11-15) [3], [4], [9], [10], [16].

$$
I_{L}=\left[I_{L n}+K_{i}\left(T-T_{n}\right)\right] \frac{G}{G_{n}}
$$

where $I_{L}$ is the light-generated current, $G$ is the surface irradiance of the cell, $T$ is the cell temperature at operating conditions, $G_{n}\left(1000 \mathrm{~W} / \mathrm{m}^{2}\right)$ is the irradiance at STC.

$$
I_{o}=\frac{I_{s c n}+K_{i}\left(T-T_{n}\right)}{\exp \left(\frac{V_{o c n}+K_{v}\left(T-T_{n}\right)}{a V_{t}}\right)-1}
$$

where $I_{o}$ is the diode's reverse saturation current at operating conditions. As the diode ideality factor, $a$, changes lightly with the change of the cell temperature and the solar irradiance, $a$ is equal to $a_{n}$.

$$
\begin{gathered}
R_{s}=R_{s n} \\
R_{p}=R_{p n} \frac{G_{n}}{G}
\end{gathered}
$$

where $R_{s n}$ is the series resistance and $R_{p n}$ is the parallel resistance at STC. After calculating the parameters, the Eq. (1) is used to simulate the performance of the PV module at operating conditions.

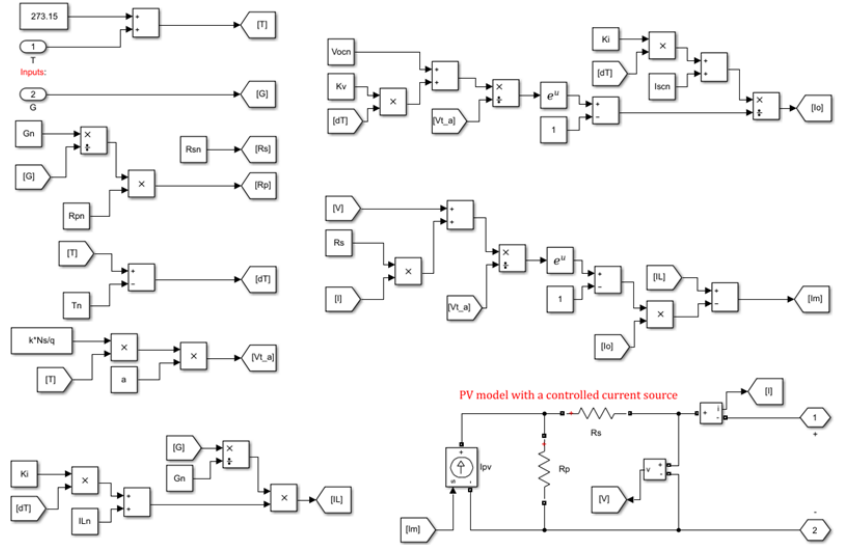

Figure 5. Simulation applied in Matlab/Simulink.

All of the parameters at reference conditions are extracted in a small software routine coded in Matlab with M language [22]. The proposed method is also simulated in Matlab/Simulink as shown in Figure 5. In the simulation, the required open-circuit voltage, $V_{o c}$ at operating conditions is calculated by the following equation:

$$
V_{o c}=V_{o c n}+K_{v}\left(T-T_{n}\right)+a V_{t} \ln \left(\frac{G}{G_{n}}\right)
$$

\section{Results and Discussion}

To confirm the accuracy of the proposed method, three commercial PV modules, the polycrystalline Kyocera KC200GT [23], monocrystalline Shell SP70 [24] and thin film Shell ST40 [25] are selected to extract reference parameters at STC. The datasheet values of the modules are listed in Table 1. Using only datasheet values in Table 1 , the methods from Villalva, Wang, and the proposed method are analyzed using the steps below.

Table 1. Datasheet values of PV modules.

\begin{tabular}{l|lll}
\hline \multirow{2}{*}{$\begin{array}{c}\text { Datasheet } \\
\text { values }\end{array}$} & \multicolumn{3}{|c}{ PV modules } \\
\cline { 2 - 4 } & KC200GT & SP70 & ST40 \\
\hline$P_{m n}(W)$ & 200.143 & 70.125 & 40.006 \\
$V_{m n}(V)$ & 26.3 & 16.5 & 16.6 \\
$I_{m n}(A)$ & 7.61 & 4.25 & 2.41 \\
$V_{o c n}(V)$ & 32.9 & 21.4 & 23.3 \\
$I_{s c n}(A)$ & 8.21 & 4.7 & 2.68 \\
$K_{v}\left(V /{ }^{\circ} \mathrm{C}\right)$ & -0.123 & -0.076 & -0.1 \\
$K_{i}\left(A /{ }^{\circ} \mathrm{C}\right)$ & 0.00318 & 0.002 & 0.00035 \\
$N_{s}$ & 54 & 36 & 36 \\
\hline
\end{tabular}

First, reference parameters are extracted by three methods coded in Matlab $M$ language with using only $V_{m n}, I_{m n}, V_{o c n}, I_{s c n}$ and $N_{s}$ values provided in datasheets. Then, extracted parameters are used to simulate $I-V$ and $P-V$ curves through the simulation implemented in Matlab/Simulink as illustrated in Figure 5. The extracted parameters of PV modules KC200GT, 
SP70 and ST40 by three methods are listed in Table 2, Table 3 and Table 4 respectively. While extracting parameters with Villalva's method, tol value of 0.001 defining maximum tolerable power error and $R_{s n}$ increment value of 0.001 are used. For the proposed method, we used tol value of 0.0001 defining maximum tolerable resistance difference. $a_{n}=1.3$ is used for monocrystalline and polycrystalline and $a_{n}=1.6$ is used for thin film PV modules in all of the methods.

Table 2. Extracted parameters of three methods for KC200GT.

\begin{tabular}{l|lll}
\hline \multirow{2}{*}{ Parameters } & \multicolumn{3}{|c}{ Method } \\
\cline { 2 - 4 } & Villalva [4] & Wang [9] & $\begin{array}{l}\text { The } \\
\text { proposed } \\
\text { method }\end{array}$ \\
\hline$a_{n}$ & 1.3 & 1.3 & 1.3 \\
$I_{\text {on }}(A)$ & $9.75 \times 10^{-08}$ & $9.83 \times 10^{-08}$ & $9.83 \times 10^{-08}$ \\
$I_{\text {Ln }}(A)$ & 8.2138 & 8.2132 & 8.2132 \\
$R_{\text {Sn }}(\Omega)$ & 0.228 & 0.2291 & 0.2291 \\
$R_{\text {pn }}(\Omega)$ & 510.88 & 593.24 & 593.29 \\
\hline
\end{tabular}

Table 3. Extracted parameters of three methods for SP70.

\begin{tabular}{l|lll}
\hline \multirow{2}{*}{ Parameters } & \multicolumn{3}{|c}{ Method } \\
\cline { 2 - 4 } & Villalva [4] & Wang [9] & $\begin{array}{l}\text { The } \\
\text { proposed } \\
\text { method }\end{array}$ \\
\hline$a_{n}$ & 1.3 & 1.3 & 1.3 \\
$I_{\text {on }}(A)$ & $8.44 \times 10^{-08}$ & $8.76 \times 10^{-08}$ & $8.76 \times 10^{-08}$ \\
$I_{L n}(A)$ & 4.7163 & 4.7132 & 4.7132 \\
$R_{S n}(\Omega)$ & 0.3910 & 0.4081 & 0.4080 \\
$R_{p n}(\Omega)$ & 113.52 & 145.44 & 145.45 \\
\hline
\end{tabular}

Table 4. Extracted parameters of three methods for ST40.

\begin{tabular}{l|lll}
\hline \multirow{2}{*}{ Parameters } & \multicolumn{3}{|c}{ Method } \\
\cline { 2 - 4 } & Villalva [4] & Wang [9] & $\begin{array}{l}\text { The } \\
\text { proposed } \\
\text { method }\end{array}$ \\
\hline$a_{n}$ & 1.6 & 1.6 & 1.6 \\
$I_{\text {on }}(A)$ & $3.85 \times 10^{-07}$ & $3.89 \times 10^{-07}$ & $3.89 \times 10^{-07}$ \\
$I_{L n}(A)$ & 2.6850 & 2.6805 & 2.6805 \\
$R_{S n}(\Omega)$ & 1.3240 & 1.3656 & 1.3656 \\
$R_{p n}(\Omega)$ & 722.61 & 7301.64 & 7266.08 \\
\hline
\end{tabular}

All of the extracted parameters except $R_{p n}$ are very close in the results of three compared methods. Wang et al. considered that the relatively smaller $R_{p n}$ values in the study of Villalva are caused by the limited size of $R_{s n}$ step length and tolerance band.

Calculated $P_{m}$ values' errors and their calculated derivatives $d P / d V$ are compared in Table 5 . The experimental $P_{m}$ values are from manufacturer's datasheet. In Table 5, $\Delta P_{m n}$ defines the absolute error between the stated and calculated maximum power. $\Delta d P_{m n}$ defines the absolute error for $d P / d V$ at the MPP. In the proposed method, the $\Delta P_{m n}$ errors for all PV modules are much smaller than those of both competitor methods, which proves the accuracy of our method. For $\Delta d P_{m n}$ errors, just the one for ST40 PV module is higher than the error of Wang's method. If the tol value of 0.0001 is reduced to 0.00001 to have higher precision in the proposed method, the $\Delta d P_{m n}$ errors decrease to the values of $6.01 \times 10^{-06}, 8.41 \times 10^{-06}$ and $1.78 \times 10^{-06}$ for the PV modules KC200GT, SP70, ST40 respectively.

Table 5. The absolute errors of three methods at MPP for three PV modules.

\begin{tabular}{lllll}
\hline Method & Error type & KC200GT & SP70 & ST40 \\
\hline \multirow{2}{*}{ Villalva [4] } & $\Delta P_{m n}(W)$ & $7.53 \times 10^{-04}$ & $9.03 \times 10^{-04}$ & $9.96 \times 10^{-04}$ \\
& $\Delta d P_{m n}(W)$ & 0.0798 & 0.3079 & 0.1208 \\
\hline \multirow{2}{*}{ Wang [9] } & $\Delta P_{m n}(W)$ & $9.26 \times 10^{-06}$ & $7.04 \times 10^{-06}$ & $6.63 \times 10^{-05}$ \\
& $\Delta d P_{m n}(W)$ & $4.76 \times 10^{-05}$ & $6.62 \times 10^{-05}$ & $3.10 \times 10^{-05}$ \\
\hline $\begin{array}{l}\text { The proposed } \\
\text { method }\end{array}$ & $\Delta P_{m n}(W)$ & $9.12 \times 10^{-06}$ & $6.87 \times 10^{-06}$ & $6.58 \times 10^{-05}$ \\
\hline
\end{tabular}

To compare the computation time of the three methods, each method's software routine is run ten times to capture average elapsed time. The actual and relative computation time and how many iteration steps are required for each method are listed in Table 6 . Table 6 shows that Wang's method is a lot quicker than Villalva's method. Villalva's method requires the highest iteration steps. Our proposed method is quicker than both competitor methods, besides requires the lower computational time and iteration steps. 
Table 6. The performance indicators of three methods.

\begin{tabular}{lllll}
\hline Method & $\begin{array}{l}\text { Performance } \\
\text { Indicator }\end{array}$ & KC200GT & SP70 & ST40 \\
\hline \multirow{2}{*}{ Villalva [4] } & Actual time (s) & $2.71 \times 10^{-02}$ & $3.78 \times 10^{-02}$ & $8.21 \times 10^{-02}$ \\
& Relative time & 10.78 & 14.92 & 31.87 \\
& Iteration steps & 228 & 391 & 1324 \\
\hline \multirow{2}{*}{ Wang [9] } & Actual time (s) & $2.97 \times 10^{-03}$ & $2.99 \times 10^{-03}$ & $3.08 \times 10^{-03}$ \\
& Relative time & 1.18 & 1.18 & 1.20 \\
& Iteration steps & 92 & 83 & 99 \\
The proposed & Actual time (s) & $2.52 \times 10^{-03}$ & $2.53 \times 10^{-03}$ & $2.58 \times 10^{-03}$ \\
method & Relative time & 1 & 1 & 1 \\
& Iteration steps & 14 & 14 & 14 \\
\hline
\end{tabular}

In order to compare Wang's method and the proposed method at various temperatures and constant irradiance $\left(1000 \mathrm{~W} / \mathrm{m}^{2}\right)$, the relative errors between the calculated and the experimental data of the PV modules SP70 and ST 40 are listed in Table 7 and Table 8.
In Table 7, the greatest error of $P_{m}$ is $1.02 \%$, and the greatest error of $V_{m}$ is $0.54 \%$. In Table 8 , the greatest error of $P_{m}$ is $2.92 \%$, and the greatest error of $V_{m}$ is $1.28 \%$. The proposed method gives closer results to the experimental values than Wang's method in a wide temperature range.

Table 7. SP70 relative errors at the MPP for various temperatures.

\begin{tabular}{|c|c|c|c|c|c|c|}
\hline \multirow[b]{2}{*}{$\mathrm{T}\left({ }^{\circ} \mathrm{C}\right)$} & \multirow[b]{2}{*}{ Parameter } & \multirow{2}{*}{$\begin{array}{l}\text { Experimental } \\
\text { value }\end{array}$} & \multicolumn{2}{|c|}{ Wang [9] } & \multicolumn{2}{|c|}{ The proposed method } \\
\hline & & & $\begin{array}{l}\text { Calculated } \\
\text { value }\end{array}$ & $\begin{array}{l}\text { Relative } \\
\text { error }\end{array}$ & $\begin{array}{l}\text { Calculated } \\
\text { value }\end{array}$ & $\begin{array}{c}\text { Relative } \\
\text { error }\end{array}$ \\
\hline \multirow{2}{*}{50} & $P_{m}(W)$ & 62.13 & 61.57 & $0.90 \%$ & 61.81 & $0.52 \%$ \\
\hline & $V_{m}(V)$ & 14.60 & 14.62 & $0.14 \%$ & 14.61 & $0.07 \%$ \\
\hline \multirow{2}{*}{25} & $P_{m}(W)$ & 70.00 & 70.13 & $0.19 \%$ & 70.12 & $0.17 \%$ \\
\hline & $V_{m}(V)$ & 16.50 & 16.50 & $0.00 \%$ & 16.50 & $0.00 \%$ \\
\hline \multirow{2}{*}{0} & $P_{m}(W)$ & 77.88 & 78.73 & $1.09 \%$ & 78.40 & $0.67 \%$ \\
\hline & $V_{m}(V)$ & 18.40 & 18.44 & $0.22 \%$ & 18.43 & $0.17 \%$ \\
\hline \multirow{2}{*}{-25} & $P_{m}(W)$ & 85.75 & 87.35 & $1.87 \%$ & 86.62 & $1.02 \%$ \\
\hline & $V_{m}(V)$ & 20.30 & 20.42 & $0.59 \%$ & 20.41 & $0.54 \%$ \\
\hline
\end{tabular}

To confirm the accuracy of the proposed method under real operating conditions, a real outdoor measurement dataset is used provided by NREL [26]. The publicly available dataset includes one-year period measurements from various PV modules representing different PV technologies. The measurement data were collected with data acquisition systems calibrated by NREL. The instant irradiance on the plane of the modules, the cell temperature, electrical outputs, and the measurement timestamp are included in the dataset. In this paper, one-day long measurement data of five different days from a polycrystalline PV module are selected for a comparative assessment. The reason for selecting a polycrystalline PV module is it's having a market share of $62 \%$ in 2017 [27]. The measurement location of the selected data was Cocoa, Florida which has a subtropical climate. Table 9 gives the datasheet values of the selected PV module.

Table 8. ST40 relative errors at the MPP for various temperatures.

\begin{tabular}{|c|c|c|c|c|c|c|}
\hline \multirow[b]{2}{*}{$\mathrm{T}\left({ }^{\circ} \mathrm{C}\right)$} & \multirow[b]{2}{*}{ Parameter } & \multirow{2}{*}{$\begin{array}{l}\text { Experimental } \\
\text { value }\end{array}$} & \multicolumn{2}{|c|}{ Wang [9] } & \multicolumn{2}{|c|}{ The proposed method } \\
\hline & & & $\begin{array}{l}\text { Calculated } \\
\text { value }\end{array}$ & $\begin{array}{l}\text { Relative } \\
\text { error }\end{array}$ & $\begin{array}{l}\text { Calculated } \\
\text { value }\end{array}$ & $\begin{array}{l}\text { Relative } \\
\text { error }\end{array}$ \\
\hline
\end{tabular}




\begin{tabular}{cllllll}
\hline \multirow{2}{*}{50} & $P_{m}(W)$ & 34.00 & 33.51 & $1.44 \%$ & 33.51 & $1.44 \%$ \\
& $V_{m}(V)$ & 14.10 & 14.28 & $1.28 \%$ & 14.28 & $1.28 \%$ \\
\multirow{2}{*}{25} & $P_{m}(W)$ & 40.00 & 40.00 & $0.00 \%$ & 40.00 & $0.00 \%$ \\
& $V_{m}(V)$ & 16.60 & 16.60 & $0.00 \%$ & 16.60 & $0.00 \%$ \\
\multirow{2}{*}{0} & $P_{m}(W)$ & 46.00 & 46.70 & $1.52 \%$ & 46.66 & $1.44 \%$ \\
& $V_{m}(V)$ & 19.10 & 19.01 & $0.47 \%$ & 19.01 & $0.47 \%$ \\
\multirow{2}{*}{-25} & $P_{m}(W)$ & 52.00 & 53.55 & $2.98 \%$ & 53.52 & $2.92 \%$ \\
& $V_{m}(V)$ & 21.60 & 21.51 & $0.42 \%$ & 21.51 & $0.42 \%$ \\
\hline
\end{tabular}

Table 9. Datasheet values of the PV module selected for comparison.

\begin{tabular}{llllllll}
\hline$P_{m n}(W)$ & $V_{m n}(V)$ & $I_{m n}(A)$ & $V_{o c n}(V)$ & $I_{s c n}(A)$ & $K_{v}\left(V /{ }^{\circ} \mathrm{C}\right)$ & $K_{i}\left(A /{ }^{\circ} \mathrm{C}\right)$ & $N_{s}$ \\
\hline 46.091 & 18.29 & 2.52 & 22.07 & 2.728 & -0.07283 & 0.00136 & 36 \\
\hline
\end{tabular}

The measured data was in 5 minutes gap for irradiance and temperature in real operating conditions. The proposed $P_{m}$ values are extracted from the simulation of the proposed method for the same operating conditions. Plots for the measured and proposed $P_{m}$ values according to the time of measurement are shown in Figs. 6-9. As seen in Figs. 6-9, the proposed values are very close to the measured ones with a very small difference.

The root mean square errors (RMSE) and mean absolute errors (MAE) of the proposed $P_{m}$ values with respect to the measured $P_{m}$ data are listed in Table 10. The values of RMSE and MAE indicate that that the proposed method can provide quite accurate results even in operating conditions.
Table 10. RMSE and MAE of the proposed $P_{m}$ curves.

\begin{tabular}{ccc}
\hline Date & RMSE & MAE \\
\hline 27th of Jul. 2011 & 0.225 & 0.19 \\
31th of Aug. 2011 & 0.4705 & 0.3627 \\
05th of Dec. 2011 & 0.5367 & 0.5024 \\
19th of Jan. 2012 & 0.9164 & 0.8614 \\
\hline
\end{tabular}

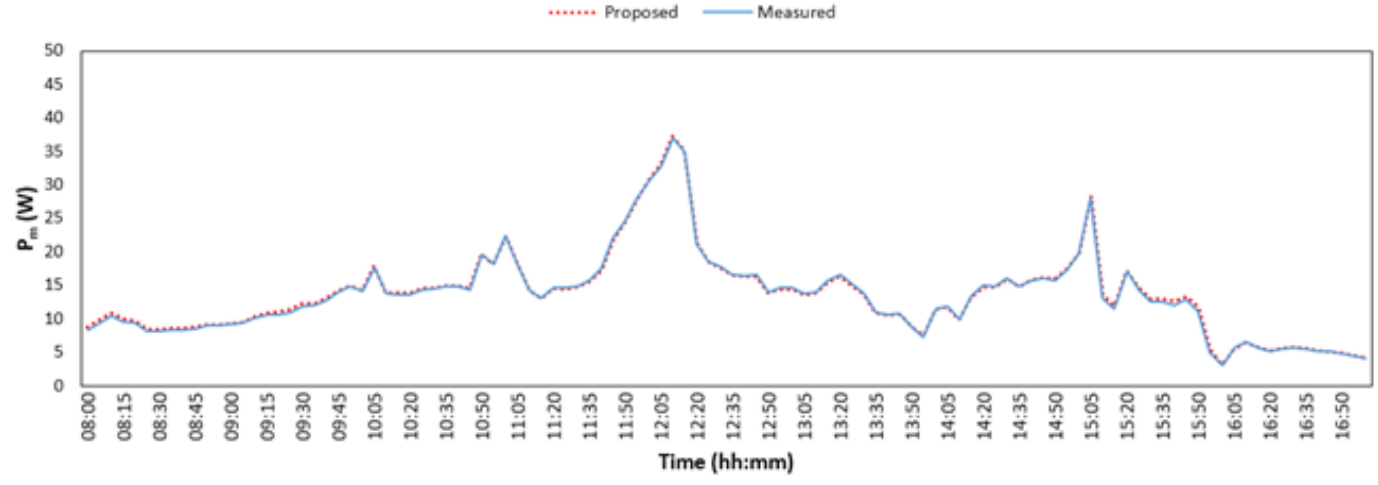

Figure 6. The measured and proposed power output values for 27th of July 2011. 


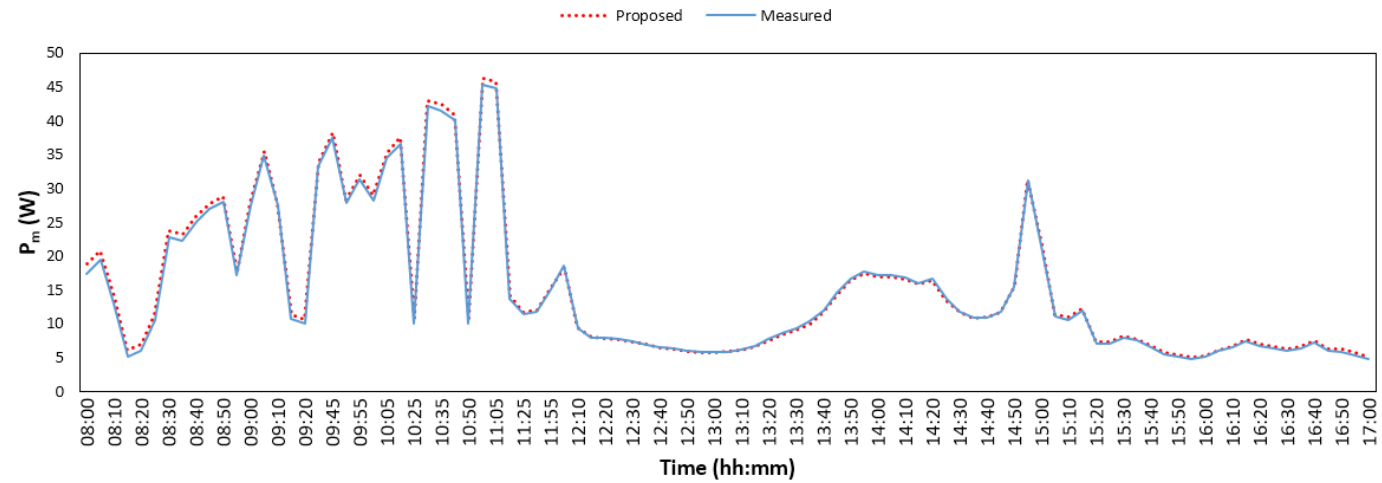

Figure 7. The measured and proposed power output values for 31th of August 2011.

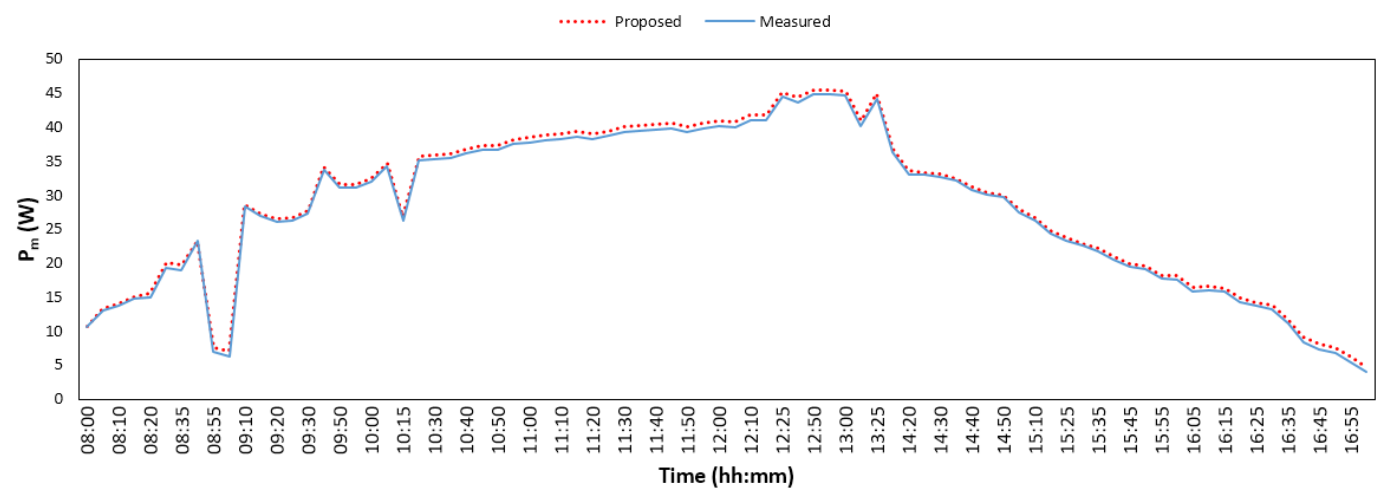

Figure 8. The measured and proposed power output values for 05th of December 2011.

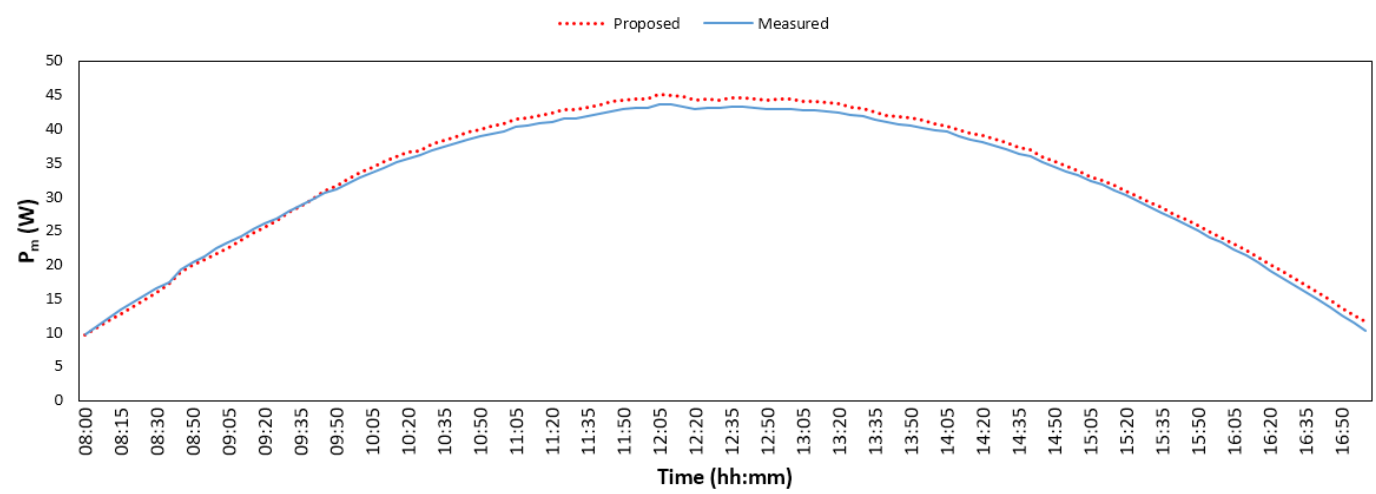

Figure 9. The measured and proposed power output values for 19th of January 2012.

\section{Conclusion}

In this paper, a new method based on the five-parameter model is presented. This method requires only manufacturer's datasheet values, avoids solving implicit equations and decreases computational complexity. We introduce a new iterative approach for extracting PV modules parameters at reference conditions. This approach uses the bisection search algorithm to find the exact pair of series and parallel resistances that guarantees that the voltage-derivative of the power equals zero at the MPP. As a result, suggested algorithm finds the appropriate serial and parallel resistance, using much lower iteration steps than linear approximation.

The proposed method can reproduce the $I-V$ and $P-V$ characteristics of PV systems at any operating conditions. The reliability of our method is confirmed by checking with both the experimental data of three kinds of PV modules and real outdoor measurement dataset provided by NREL. The results have demonstrated that the proposed method is a powerful and promising method that can accomplish both higher accuracy and lower computational time according to its competitors.

\section{References}

[1] J. Duffie and W. Beckman, "Solar Engineering of Thermal Processes, 2th ed.," p. 919, 1991.

[2] M. A. De Blas, J. L. Torres, E. Prieto, and A. García, "Selecting a suitable model for characterizing photovoltaic devices," Renew. Energy, vol. 25, no. 3, pp. 371-380, 2002.

[3] A. N. Celik and N. Acikgoz, "Modelling and experimental verification of the operating current of mono-crystalline photovoltaic 
modules using four- and five-parameter models," Appl. Energy, vol. 84, no. 1, pp. 1-15, 2007.

[4] M. Villalva, J. Gazoli, and E. Filho, "Comprehensive Approach to Modeling and Simulation of Photovoltaic Arrays," IEEE Trans. Power Electron., vol. 24, no. 5, pp. 1198-1208, 2009.

[5] V. Lo Brano, A. Orioli, G. Ciulla, and A. Di Gangi, "An improved five-parameter model for photovoltaic modules," Sol. Energy Mater. Sol. Cells, vol. 94, no. 8, pp. 1358-1370, 2010.

[6] A. Chouder, S. Silvestre, N. Sadaoui, and L. Rahmani, "Modeling and simulation of a grid connected PV system based on the evaluation of main PV module parameters," Simul. Model. Pract. Theory, vol. 20, no. 1, pp. 46-58, 2012.

[7] A. Orioli and A. Di Gangi, "A procedure to calculate the five-parameter model of crystalline silicon photovoltaic modules on the basis of the tabular performance data," Appl. Energy, vol. 102, pp. 1160-1177, 2013.

[8] J. Y. Park and S. J. Choi, "A novel datasheet-based parameter extraction method for a single-diode photovoltaic array model," Sol. Energy, vol. 122, pp. 1235-1244, 2015.

[9] G. Wang et al., "An iterative approach for modeling photovoltaic modules without implicit equations," Appl. Energy, vol. 202, pp. 189-198, 2017.

[10] W. De Soto, S. A. Klein, and W. A. Beckman, "Improvement and validation of a model for photovoltaic array performance," Sol. Energy, vol. 80, no. 1, pp. 78-88, 2006.

[11] J. Bai, S. Liu, Y. Hao, Z. Zhang, M. Jiang, and Y. Zhang, "Development of a new compound method to extract the five parameters of $\mathrm{PV}$ modules," Energy Convers. Manag., vol. 79, pp. 294-303, 2014.

[12] E. I. Batzelis and S. A. Papathanassiou, "A Method for the Analytical Extraction of the Single-Diode PV Model Parameters," IEEE Trans. Sustain. Energy, vol. 7, no. 2, pp. 504-512, 2016.

[13] F. Rasool, M. Drieberg, N. Badruddin, and B. S. Mahinder Singh, "PV panel modeling with improved parameter extraction technique," Sol. Energy, vol. 153, pp. 519-530, 2017.

[14] J.Y. Park and S. J. Choi, "A novel simulation model for PV panels based on datasheet parameter tuning," Sol. Energy, vol. 145, pp. 90-98, 2017.

[15] Y. Chaibi, M. Salhi, A. El-jouni, and A. Essadki, "A new method to extract the equivalent circuit parameters of a photovoltaic panel," Sol. Energy, vol. 163, no. January, pp. 376-386, 2018.

[16] V. J. Chin, Z. Salam, and K. Ishaque, "Cell modelling and model parameters estimation techniques for photovoltaic simulator application: A review," Appl. Energy, vol. 154, no. September, pp. 500519, 2015.

[17] A. H. Arab, F. Chenlo, K. Mukadam, and J. L. Balenzategui, "Performance of PV water pumping systems," Renew. Energy, vol. 18, no. 2, pp. 191204, 1999.

[18] G. Ciulla, V. Lo Brano, V. Di Dio, and G. Cipriani, "A comparison of different one-diode models for the representation of I-V characteristic of a PV cell," Renew. Sustain. Energy Rev., vol. 32, pp. 684-696, 2014.

[19] A. R. Jordehi, "Parameter estimation of solar photovoltaic (PV) cells: A review," Renew. Sustain. Energy Rev., vol. 61, pp. 354-371, 2016.

[20] G. Walker, "Evaluating Mppt Converter Topologies Using a Matlab Pv Model," J. Electr. Electron. Eng., vol. 21, no. 1, pp. 49-56, 2001.

[21] G. Wang, K. Zhao, T. Qiu, X. Yang, Y. Zhang, and Y. Zhao, "The error analysis of the reverse saturation current of the diode in the modeling of photovoltaic modules," Energy, vol. 115, pp. 478485, 2016.

[22] “Matlab." Mathworks, 2017.

[23] “KC200GT Datasheet," Kyocerasolar.com, 2018. [Online]. Available: https://www.kyocerasolar.com/dealers/produc t-center/archives/spec-sheets/KC200GT.pdf. [Accessed: 20-Mar-2018].

[24] “SP70 Datasheet," solenerg.com.br, 2018. [Online]. Available: http://www.solenerg.com.br/files/SP70.pdf. [Accessed: 20-Mar-2018].

[25] "ST40 Datasheet," atlantasolar.com, 2018. [Online]. Available: http://www.atlantasolar.com/pdf/Shell/ShellST 40_USv1.pdf. [Accessed: 20-Mar-2018].

[26] B. Marion et al., "New data set for validating PV module performance models," in 2014 IEEE 40th Photovoltaic Specialist Conference (PVSC), 2014, pp. 1362-1366.

[27] “Photovoltaics Report," 2016. [Online]. Available: https://www.ise.fraunhofer.de/content/dam/is e/de/documents/publications/studies/Photovol 
taics-Report.pdf. [Accessed: 24-Apr-2018].

\section{Appendix A}

Please refer to the link below to download the code of this paper: https://github.com/ckapucu/bisectionsearch and refer the link below to download the Matlab/Simulink model: https://github.com/ckapucu/pvmodel. 